Thematic Article

\title{
Criteria determining school choice among the ethnic minority high school students
}

\author{
Imre Tódor ${ }^{1}$ \\ Recommended citation: \\ Tódor, I. (2020). Criteria determining school choice among the ethnic minority high school students. Central \\ European Journal of Educational Research, 2(1), 17 - 25.
}

\begin{abstract}
In our paper we sought for the answer to the question: based on which motives do students from various types of high schools (in our case, denominational or non- denominational school) make their choice of educational institution? The target group of our research consists of the 9th and 11th grade students of Harghita County's denominational (Roman Catholic, Reformed, Unitarian) schools and the non-denominational ones added to them. All in all, eight high schools got into our sample. We conducted a survey by questionnaire, the sample including 1,064 people. We analyzed the decision criteria formed based on motives behind the decision (primary and secondary effects) on the one hand, and followed the decision-making process on the other. The non-denominational sector is often chosen by the elite- and institution-oriented student group, who has great expectations of the institution, e.g. - top of the line standards of education, outstanding achievement indicators, prestige of the institution, local reputation. According to the clusters created from the motives, the value- and community-oriented student group, as well as the one following the orientation of the peer group, can be found in significantly higher proportion in denominational schools.
\end{abstract}

Keywords: denominational school; non-denominational school; school choice; Harghita County

\section{Introduction}

School choice is a research field of educational sociology that has a long tradition. (cf. Maaz et al. 2006). Above all, the analyses of the social selection mechanisms associated with it have become more intensely focused on by social scientists. In educational science research, countless subfields analyse the environment surrounding the decision, especially the ones that offer cross-sectional branches. Among them, thematising the school choice of the student and/or parent that determines the life of the individual later on is of paramount importance.

In our paper, we seek the answer to the substantive question, along which criterial lines do students decide on one or another type of school? Which are the determinant arguments that serve as a basis for the decision-making process? The multi-faceted issue formulates a multi-stage research objective. In the choice of the school users (students as well as parents), do norms, values and religiosity represented by denominational schools play a role? Can we talk about sector-specific decision motivation? What constitutes the differentia specifica of the decision mechanisms of secular and denominational school choosers? The need for the cross-sectoral research came to the foreground in the middle of the 20th century, due to economic (investment-return rate) and education policy.

The German research literature primarily analyses the parents' motivations in connection with school choice, as it is the parents who decide about the education of their children. At lower levels (ISCED 1-2), it is really the parent who makes decisions, whereas at higher levels (ISCED 3-4 etc.), the freedom and responsibility of choice lays upon the student (as well). However, other authors tried to reconstruct the family decisions based on the students' data.

1 Sapientia Hungarian University of Transylvania, Cluj-Napoca, Romania; todorimre@uni.sapientia.ro 
Koinzer - Gruehn (2013) describe the issue of school choice along with the results of two empirical researches carried out among parents (Heidelberg's Montessori school and Berlin's Jewish school). In line with the results of both studies, the parents' motivations are indicated by facts such as teaching methods, school atmosphere, the pedagogical programme of the school, good school management, class size, the safety of children, school reputation etc. Schelander (2013) made his empirical study together with the research carried out by Hanisch - Gramzow (2011) in Germany a few years before. Both empirical studies ask about parents' motivation for choosing Evangelical-run schools.

Hanisch - Gramzow conducted a survey among the parents of the students of 18 Evangelical schools belonging to the Evangelical church district of North Elba as well as Pomerania and Mecklenburg. As a result, in the following year (2012) they extended their research to Saxony (Sachsen) as well. According to this research, pedagogical reasons are relevant in the parents' decisions. The 27 motives named by the parents were reduced to five by the researchers following factor analysis: 1. pedagogical reasons (e.g. education reform concept), 2. religious identity, 3. the principle of comparison to state schools and rejection, 4. extracurricular activities, and finally 5 . pragmatic reasons (e.g. school proximity and accessibility).

Schelander (2013) carried out a similar empirical research study among the parents of the students of Vienna's Evangelical schools. Following an (on-line) full inquiry, 448 parents responded from the existing nine Evangelical schools. Pragmatic reasons do not play a decisive role in school choice here either, but the (familial, friendly) atmosphere of the school, the existence of the medium of socialisation, etc. are conclusive. In a similar study, Clausen (2006) analyses the fact of school choice in two cities of the State of Baden-Württemberg (Mannheim and Heidelberg), though it was within a training process (Gymnasium and Realschule) rather than a denominational, intersectoral one.

The interview analyses carried out within the region earlier also report on the fact that, with the institution choice motivation, in several cases the school's "level" is one of the main driving forces for both parents and students (cf. Mandel - Papp Z. 2007). The conclusion of the interview analyses is that students and "parents decide on a high school based on the reputation and tradition of the institution" (Mandel-Papp Z. 2007: 146).

\section{Methodology}

The target group of our research is constituted by $9^{\text {th }}$ and $11^{\text {th }}$ grade students of denominational and non-denominational schools of Harghita County fitted to them (ISCED 3). The reason for which the survey was carried out during these two years is that they represent the entrants of the lower and upper secondary school. In Romania, students start their high school education following the 8th grade, whose lower secondary level is constituted by the obligatory section (9-10 grades), while the upper secondary level by the non-compulsory section (11-12 grades). The survey of the ninth-grade students related to their aspirations was conducted in the previous year (during the 8th grade); at the same time, the mechanism of their decision is still vivid in their memories, which enables us to measure the entrants' motivations, requirements and expectations alike.

We applied a multi-stage cluster sampling. At the first stage, all the denominational schools operating under the auspices of Hungarian historic churches in Harghita County were included in the sampling, and we fitted non-denominational schools to them. The selection of the nondenominational schools and their adaption to the denominational ones were carried out in such a way that the indicators should be similar to the settlement, type of residence and to the social situation of their student society (cf. Pusztai 2009). Beside the previous field experience, the official national "ranking", based on the school's input/ output study outcomes and achievements, provided a good basis for this. Thus, eight schools were selected: four (fully) denominational (two RomanCatholic, one Reformed and one Unitarian) and four non-denominational schools.

At the second stage of the sampling, the selection of the students was carried out within the schools. We did a full questionnaire survey among the 9th and 11th grade students. Out of the population of 1,205 there were 1,064 respondents, thus we managed to reach $88,29 \%$ of the target group. The survey took place between 16 April 2018 - 23 May 2018 in the form of paper 
questionnaires. Our HR-CSC 2018 database was recorded and processed with the help of the SPSS 22.0 statistical program package. The 46 , both closed and open questions on the questionnaire can be grouped into seven main categories.

Regarding our first research question, based on the national and international literature, we would expect the school quality (high academic standards) as well as the proximity of the school to be dominant among the most important criteria. According to the empirical data of the denominational education research, this would be completed by the tradition, ethos (the religious profile) as well as the climate of the school (Hanisch-Gramzow 2011; Pusztai 2009; Schelander 2012 etc.). With our second research question we sought the answer to the nature of correlation between the decision criteria and the school type chosen by students. Based on the national and international literature (cfr. Clausen 2006; OECD 2019), we would expect that the existence of the favourable quality indicators (school level, quality, reputation) play the main role in the attractiveness of nondenominational schools; whereas the attractiveness of denominational schools is indicated by the personal attention, the "family atmosphere", the cohesive strength of the community (cfr. Pusztai 2015).

\section{Results}

To test our hypotheses, we apply the following statistical methods. The students' school choice decision motives are first interpreted using univariate analysis (descriptive statistics/ frequencies), then its cross-sector comparison is interpreted using bivariate analysis (crosstabs). Further on, with the help of the data reduction method (cluster analysis), student groups are separated on the basis of their decision criteria. Finally, the student clusters thus created are analysed in a cross-sector breakdown as well as by school type and profile.

Table 1. School choice decision criteria ( $\mathrm{N}=1062$; percentage)

\begin{tabular}{clc}
\hline 1. & The high academic standards of the school & 76,3 \\
2. & Good, qualified teachers & 50,3 \\
3. & Good community & 48,6 \\
4. & My friends, classmates also came here & 43,1 \\
5. & The profiles offered by the school & 41,6 \\
6. & My family also attended this school & 38,7 \\
7. & The school climate & 36,4 \\
8. & The proximity of the school & 30,6 \\
9. & The school facilities (infrastructure) & 30,1 \\
10. & The tradition, spirit and religious education of the school & 25,1 \\
\hline
\end{tabular}

Source: HR-CSC 2018; author's own editing

The students have to name the first, second as well as the third reasons out of the ten mentioned for which they chose the given school. Our results show that the high academic standards of the school ranks first among the criteria of the total sample (not the primary criteria order!), which was a criterion chosen by more than three-fourths of the students. The decision of more than half of the students was greatly influenced, next to high standards, by the presence of good, qualified teachers, together with whom that particular high level can be ensured. The importance of the existence of all these may be intended to support the students' aspirations of further education. From the influencing factors of the two reasons, the prestige of the educational institution, elitism can be deduced. To almost half of the students, the existence of the good school and class community meant the following, also dominant criterion. This is followed by my friends, classmates also came here as well as the profiles offered by the school in the overall ranking, which were named by over $40 \%$ of the students. The decision among the next five preferences is between $25-40 \%$.

The reasons indicated as the least important ones include the proximity of the school, school facilities as well as the tradition, spirit and religious education of the school. From the overall reasons we can conclude that the school location (accessibility), the condition of its building and classrooms, as well 
as its tradition and educational principles are not main priorities; while school prestige, its good community joined by already existing friends as well as the good teachers teaching there are the students' main school choice criteria.

In the next step, we are going to analyse whether naming the primary reasons differs in crosssector comparison (Table 2). In light of the results obtained we can see that the most important factor of the primary reason is still the school's high academic standard, followed by the existence of a good community. Within the overall ranking, the school's offer of profiles was the third most important aspect. The influencing motives of the good and qualified teachers as well as the good equipment (infrastructure) are thus the first five most important primary reasons. There is a significant difference in the case of the influencing factors of the high academic standards reason $\left(\chi^{2}=19,182 ; \mathrm{df}=2, \mathrm{p}=0,000\right)$, which plays a primary role in the case of $63.1 \%$ of the students choosing non-denominational schools, while merely with $48.5 \%$ of the students choosing denominational schools.

Table 2. School choice decision criteria in cross-sector comparison (N=1062; percentage)

\begin{tabular}{lcccccc}
\hline & \multicolumn{3}{c}{ non-denominational } & \multicolumn{3}{c}{ denominational } \\
& I. & II. & III. & I. & II. & III. \\
\hline The high academic standards of the school *** & $\mathbf{6 3 , 1}$ & 21,3 & 15,6 & 48,5 & $\mathbf{3 5 , 3}$ & 16,2 \\
Good, qualified teachers *** & $\mathbf{3 6}$ & 40,9 & 23,1 & 26,9 & 37,2 & $\mathbf{3 5 , 9}$ \\
Good community ** & $\mathbf{4 1 , 5}$ & 31,5 & 27 & 29,1 & 35,8 & $\mathbf{3 5 , 1}$ \\
My friends, classmates also came here & 22,2 & 35,7 & 42,1 & 25,9 & 34,6 & 39,5 \\
The profiles offered by the school * & 39,9 & $\mathbf{3 7 , 5}$ & 22,6 & $\mathbf{5 1 , 4}$ & 25,7 & 22,9 \\
My family also attended this school & 24,1 & 27,7 & 48,2 & 32 & 23 & 45 \\
The school climate & 29,8 & 41,6 & 28,6 & 35,6 & 36,3 & 28,1 \\
The proximity of the school *** & 22,8 & $\mathbf{4 5 , 6}$ & 31,6 & 23,9 & 27,2 & $\mathbf{4 8 , 9}$ \\
The school facilities (infrastructure) & 31,4 & 44,1 & 24,5 & 29 & 38 & 33 \\
The tradition, spirit and religious education of the school & 19,3 & 37 & 43,7 & 25,7 & 32,9 & 41,4 \\
\hline
\end{tabular}

Source: HR-CSC 2018; author's own editing

The significance level of the correlation is: ${ }^{*} p \leq 0,05 ;{ }^{* *} p \leq 0,01 ;{ }^{* * *} p \leq 0,001$.

The values in bold indicate that the percentage in the given cell is higher than expected in a random distribution (Adj. Stand. Res.: $\geq 2.0$ ).

Further significant differences can be seen in the case of such motives as good, qualified teachers $\left(\chi^{2}=10,114 ; \mathrm{df}=2, \mathrm{p}=0,006\right)$ as well as good community $\left(\chi^{2}=8,189 ; \mathrm{df}=2, \mathrm{p}=0,017\right)$. The latter testifies the importance of the personal relationships and that of belonging to a community, whereas the former follows the logic of the first two reasons (school quality, offer). It is important to note the crucial role that the existence of good teachers plays in the students' high school choice as well. The primacy of the motivation present in elementary school choice, where parents choose a teacher rather than a school, is also reflected in the case of the high school: the person of the teacher is also an essential factor, not only the school in and of itself. That is, the institutions are not judged based on the work of a certain person but the work of the entire teacher community is considered (Bodó-Márton 2012). In both cases, the impact of the indicated influencing factors is higher among the students choosing nondenominational schools: good community (non-denominational: 41.5\%, denominational: $29.1 \%$ ), good, qualified teachers (non-denominational: $36 \%$, denominational: $26.9 \%$ ).

The primary reasons are followed by the school climate and my family also attended this school variables. The former factor influencing school choice is more characteristic to the decision mechanisms of students choosing denominational schools, yet we found no significant difference. We have seen that the school's tradition, spirit and religious education is in the penultimate place in the overall ranking, yet, in cross-sector breakdown, it is more decisive for the students choosing denominational schools: non-denominational $19.3 \%$, denominational $25.7 \%$. Students can also well perceive that the mission and task of denominational schools do not only manifest in the objectively measurable high efficiency, but also in the students' education, socialisation named the subjective dimension of efficiency. The high rate naming of the influencing factor my (nuclear) family members also attended this school among the students choosing denominational schools refers to siblings rather than parents, since denominational schools were re-organised only after 1990. My friends, classmates 
also came here as well as the school traditions and spirit are the primary reasons least influencing school choice. Both reasons appear as more significant effects for students choosing denominational schools, yet we found no significant difference.

In the table above (Table 2) we can see that the offer of the school in the case of the third most important reason shows a difference larger than expected with the students choosing the denominational sector, which indicates a significant difference $\left(\chi^{2}=5,849 ; \mathrm{df}=2, \mathrm{p}=0,044\right)$. We mentioned earlier that one of the classes of the denominational schools is of theological profile, into which only students who take a so-called talent test of religion before the national examinations can enroll. Actually, there is no difference in offer between the two sectors, since theological classes can also be found in some non-denominational schools, while the science and humanities specialisations present in non-denominational schools can also be found in denominational schools. The only difference is that non-denominational schools have higher enrollment, thus they can start more classes and combine foreign languages or informatics with them. For instance, mathematicsinformatics - intensive English, mathematics-informatics - intensive informatics, social sciences intensive German/Italian etc., actually they can only enrich their offer this way in comparison to the denominational sector.

In the case of the overall reasons we also find a significant difference $\left(\chi^{2}=10,562 ; \mathrm{df}=2, \mathrm{p}=0,005\right)$ in the school proximity criterion. It can be seen that values greater than expected are to be found at the second most important reason with the students choosing non-denominational schools (nondenominational: $45.6 \%$; denominational: $27.2 \%$ ), whereas in the case of naming the third most important reason, we find greater than expected values with the students choosing denominational schools (non-denominational: $31.6 \%$; denominational: $48.9 \%$ ).

Overall, we can say that marked differences can be seen in the decision mechanisms of the students choosing the two school types. The non-denominational student group is more likely influenced by the school quality, the good and qualified teachers and good community reasons, while those choosing denominational schools, the offer of profiles, the school tradition, spirit and following family members play a more important role. Our results are largely in line with the literature studied, namely, the quality of the school plays the most important role in the case of this student group, whereas the proximity of the school does not play an essential role at all in the students' school choice in the case of our sample. In cross-sector comparison, besides the school tradition and spirit motive we would also have associated the good community factor with students choosing denominational schools, while the latter plays an eminent role in the decision criterion of the students choosing the non-denominational sector.

Following our uni- and bivariable, mostly descriptive statistical analysis, we make a further step and deepen our analysis with the data reduction of the students' school choice criteria. Hereinafter, the question block consisting of ten variables are organised into homogenous, well-distinguishable groups with the help of cluster analysis. First we chose the hierarchical cluster analysis procedure, followed by the K-means cluster analysis procedure due to the high number of elements; then, we compared the results for reliability. In the course of the analysis, we ran three-, four- and five-cluster versions, then, following the analysis of the final cluster centres, we finally decided on the four-cluster solution also because of the good interpretability of the variables. Among the variables included in the cluster analysis we found no protruding elements, at the same time we examined the correlation between the variables and found weak and moderate correlations $(r<0,30)$, that is, they did not correlate too strongly with each other, thus the variables fulfilled this condition as well. 
Table 3. Clusters created on the basis of the criteria influencing students' high school choice $(\mathrm{N}=1060)$

\begin{tabular}{|c|c|c|c|c|}
\hline \multirow[b]{2}{*}{ Variable } & \multicolumn{4}{|c|}{ Clusters } \\
\hline & $\begin{array}{c}\text { Elite- } \\
\text { oriented } \\
\text { students } \\
(41,3 \%)\end{array}$ & $\begin{array}{c}\text { Peer group } \\
\text { orientation } \\
\text { following } \\
\text { students } \\
(16,8 \%)\end{array}$ & $\begin{array}{c}\text { Value- and } \\
\text { community- } \\
\text { oriented } \\
\text { students } \\
(23,5 \%)\end{array}$ & $\begin{array}{c}\text { Institution- } \\
\text { oriented } \\
\text { students } \\
(18,4 \%)\end{array}$ \\
\hline My friends, classmates also came here & + & +++ & + & ++ \\
\hline My family also attended this school & + & - & + & ++ \\
\hline $\begin{array}{l}\text { The tradition, spirit and religious education of } \\
\text { the school }\end{array}$ & + & + & ++ & ++ \\
\hline The proximity of the school & + & + & + & +++ \\
\hline The school climate & + & + & ++ & +++ \\
\hline Good, qualified teachers & + & + & + & +++ \\
\hline Good community & + & + & ++ & ++ \\
\hline The school facilities (infrastructure) & + & + & + & +++ \\
\hline The high academic standards of the school & +++ & + & - & ++ \\
\hline The profiles offered by the school & + & + & + & +++ \\
\hline $\mathbf{N}$ & 438 & 178 & 249 & 195 \\
\hline
\end{tabular}

Source: HR-CSC 2018; author's own editing

We have standardised the variables, whose average is 0 , whereas their dispersion is 1 . The positive values are above average, while the negative ones are below it. Their marks are + below average, ++ above average. The values considerably different from the average are indicated as follows: - not typical at all, +++very typical.

The table above (Table 3 ) shows that the first cluster includes the student group with the greatest number of elements, more than one-third of the students (41.3\%). According to size, the third cluster includes almost one-fourth of the students $(23.5 \%)$, while the second and the fourth clusters include student groups with roughly similar number of elements (16.8\%, respectively $18.4 \%$ ).

The largest student group of our sample is formed by the students in the first cluster, on whom the high academic standards exercise the greatest influence. We called them elite-oriented students, as for them, a reputable, prestigious school producing high effectiveness is the main motive and the only one that influences decision making. The other reasons are ignorable from their point of view and they play a less important role. For the student group belonging to the second cluster, the main reason is represented by the application of their friends and classmates to the same school, thus we called them students following peer group (friends, classmates) orientation, since in their case the peer group plays a prominent role in their school choice, while the family role has a negligible influence on it.

In the third cluster including the second largest student group we find those students on whom school tradition, spirit, climate and good community have the greatest impact. We called them valueand community-oriented students; besides, they are the only cluster for which high academic standards play the least important role in their choice. For the students belonging to the last, fourth cluster $(18.4 \%)$, every decision criterion represents a value over average, yet some variables, such as school proximity, good, qualified teachers, the school's offer and school infrastructure, approach the maximum value, thus separating them from the particularities of the other student groups. We call them institution-oriented students, a group for whose members there is no particularly prominent reason, all reasons are essential and none is irrelevant, yet the main moving force of their choice is admission to a given educational institution. With this student group, next to the Other option we found such answers as ,it is still better to be the last student in this school than the top student in the ones over the stream".2.

\footnotetext{
2 With the expression "the ones over the stream", the students refer to technical secondary schools. For this student group, the main school choice motivation lies in belonging to the institutions of great prestige.
} 
Later on, we compared the student clusters formed along their school choice motives with the variables referring to the characteristic of the school (school type and academic programs). We are curious about the features marking each and every cluster, as well as whether there are differences among them.

Table 4. Comparing clusters formed on the basis of school choice reasons of the students applying to high school with the characteristic of the school ( $\mathrm{N}=1060$; percentage)

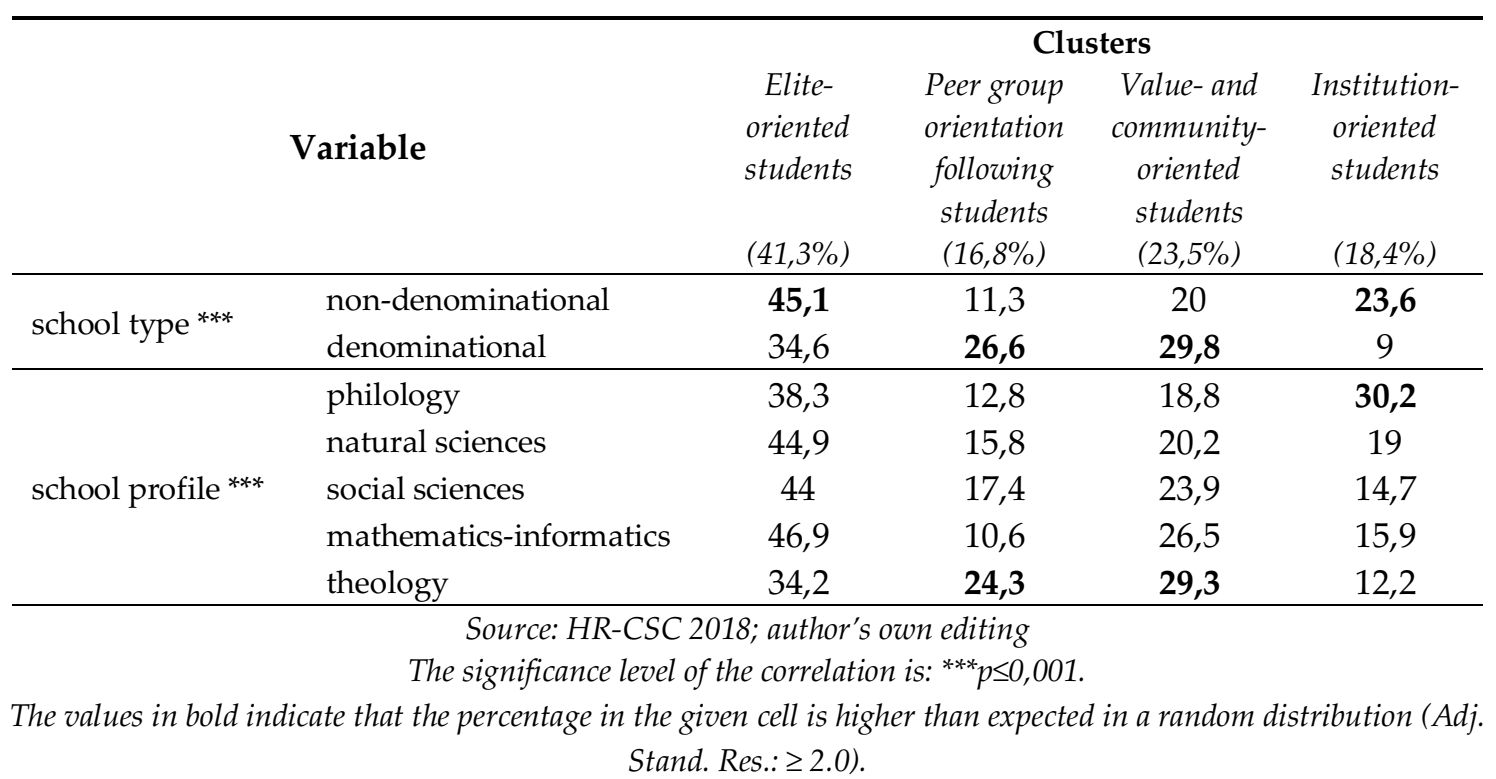

The members of the first cluster - elite-oriented students - compared to the total sample average, belong to the ones choosing non-denominational schools in a significantly higher proportion $\left(\chi^{2}\right.$ $=79,180 ; \mathrm{df}=3, \mathrm{p}=0,000$ ) and study in classes with a real specialisation (mathematics-informatics and natural sciences) profile (46.9\% and $44.9 \%$ ). In the past decade, in Romania, as in Harghita County as well, the highest admittance average is necessary for the real specialisation. The natural sciences and the mathematics-informatics profiles have the highest prestige.

The students of the second cluster - following peer group (friends, classmates) orientation -, including the smallest student group, choose the denominational sector, while regarding the training profile, they choose the theology class $\left(\chi^{2}=45,176 ; \mathrm{df}=12, \mathrm{p}=0,000\right)$. The student community $(23.5 \%)$ included in the third cluster - value-and community-oriented students -, similar to the second cluster, also chose the denominational sector and the theology profile. The theology specialisation belongs to the profile of the denominational schools, and in our data, we can see that school authority type and training type go together. The students of the fourth cluster - institution-oriented students - similarly to the first cluster, choose the non-denominational sector, while regarding specialisation, they choose the philology profile.

In the last phase of our analysis (Table 5), we were curious about the presumable relationships between the clusters formed on the basis of decision criteria and the students' primary school performance, which is the macro-level selection criterion in their application to high school. Based on our data we can conclude that the elite-oriented cluster for which, as we saw in the above analyses, the high level of school quality is the decisive factor, has the highest primary school performance. Based on all performance indicators, they have significantly better results than the student groups belonging to the other clusters. However, we also know from our analyses above that they choose non-denominational schools. At the same time, based on our previous analyses and the national high school "ranking", the non-denominational educational institutions included in our sample have higher quantitative performance indicators. The institution-oriented student cluster also has a significantly higher school performance, but their performance is lower than that of the elite-oriented student group. We also indicated in their case that, on the one hand, they choose the nondenominational school sector, on the other hand, besides the high level of the educational institution, 
its teachers, offer of profiles, good infrastructure criteria are of particular importance. The students belonging to the other two clusters have significantly lower than average school performance, which can also be explained by the fact that for them, the value system, the community, the climate and spirit of the given educational institution represent priorities.

Table 5. Comparing clusters formed on the basis of school choice reasons of the students applying to high school with the students' primary school performance ( $N=1060$; mean)

\begin{tabular}{|c|c|c|c|c|c|c|c|}
\hline & & \multirow{2}{*}{$\begin{array}{l}\text { average of } \\
\text { admissions }\end{array}$} & \multirow{2}{*}{$\begin{array}{l}\text { average } \\
\text { of the } \\
\text { National } \\
\text { Test } \\
\end{array}$} & \multirow{2}{*}{$\begin{array}{l}\text { average } \\
\text { of the } \\
\text { primary } \\
\text { school }\end{array}$} & \multicolumn{3}{|c|}{ The National Test } \\
\hline & & & & & $\begin{array}{c}\text { Romanian } \\
\text { language }\end{array}$ & Mathematics & $\begin{array}{r}\text { Hungarian } \\
\text { language }\end{array}$ \\
\hline \multirow{2}{*}{$\begin{array}{l}\text { Elite-oriented } \\
\text { students }\end{array}$} & mean & 8,37 & 8,06 & 9,49 & 7,17 & 8,16 & 8,86 \\
\hline & st. dev. & 0,91 & 1,06 & 0,44 & 1,43 & 1,48 & 0,82 \\
\hline \multirow{2}{*}{$\begin{array}{c}\text { Peer group } \\
\text { orientation } \\
\text { following students }\end{array}$} & mean & 7,84 & 7,44 & 9,26 & 6,50 & 7,41 & 8,41 \\
\hline & st. dev. & 1,16 & 1,34 & 0,59 & 1,75 & 1,78 & 1,02 \\
\hline \multirow{2}{*}{$\begin{array}{c}\text { Value- and } \\
\text { community- } \\
\text { oriented students }\end{array}$} & mean & 8,17 & 7,81 & 9,44 & 6,94 & 7,82 & 8,68 \\
\hline & st. dev. & 1,04 & 1,22 & 0,52 & 1,55 & 1,66 & 0,98 \\
\hline \multirow{2}{*}{$\begin{array}{c}\text { Institution- } \\
\text { oriented students }\end{array}$} & mean & 8,31 & 7,97 & 9,49 & 7,11 & 7,94 & 8,88 \\
\hline & st. dev. & 1,00 & 1,17 & 0,49 & 1,61 & 1,50 & 0,89 \\
\hline \multirow{2}{*}{ Total } & mean & 8,22 & 7,88 & 9,44 & 6,99 & 7,91 & 8,74 \\
\hline & st. dev. & 1,02 & 1,19 & 0,50 & 1,57 & 1,60 & 0,92 \\
\hline
\end{tabular}

\section{Conclusions}

In our study, we have analysed the decision mechanisms of students applying to high school, the main goal being to learn the reasons for which the students decide on one school or the other. We have found significant differences between the decision criteria of the students applying to denominational and non-denominational schools. For non-denominational school students, reasons related to school quality (high academic standards) appeared in first place in order of preference. In the case of denominational school students, the profile offered by the school is the dominant motive, which is in line with the expectations from the school.

While analysing the decision criteria, we presumed that in the decision process of the students with better school achievement (marks), the quality criterion (high academic standards) plays the primary role. In a cross-sector comparison we observed that, for the students choosing nondenominational schools, the primary criterion of decision is the high academic standard of the given school.

The choosers' decision regarding the school type is formed by the priority of the quality indicators of the school. In the hypothesis we expected the high educational standard, the good, qualified teachers and the school's subject offer to represent priority among the students of the nondenominational sector, and this was justified as well. Meanwhile, with the students choosing denominational schools, we expected a higher presence of motives such as a good community, the atmosphere of the school, its traditions, spirit and religious education. Based on the student clusters formed from the variables, the differences in school choice motives became clearly outlined both in their comparison to cross-sectoral and family background indicators. We found that the elite- and institution-oriented students are the students choosing the non-denominational sector in a significantly higher proportion, while the students following the peer group orientation as well as the value- and community-oriented students are the ones choosing the denominational sector in a significantly higher proportion. 


\section{References}

1. Bodó, B., \& Márton, J. (2012). Magyar iskolaválasztás Erdélyben. Kisebbségkutatás, 3, 418-472.

2. Clausen, M. (2006). Warum wählen Sie genau diese Schule? Eine inhaltsanalytische Untersuchung elterlicher Begründungen der Wahl der Einzelschule innerhalb eines Bildungsgangs. Zeitschrift für Pädagogik, 52(1), 69-90.

3. Hanisch, H., \& Gramzow, C. (2011). Elternmotive zum Besuch einer evangelischen Schule. Ergebnisse einer Befragung in Mecklenburg-Vorpommern. Zeitschrift für Pädagogik und Theologie, 63(4), 305-316.

4. Koinzer, T., \& Gruehn, S. (2013). Allgemeinbildende Privatschulen in Deutschland im Spannungsfeld von pädagogischer Innovation und rechtlichen sowie wirtschaftlichen Bedingungen - wo "die pädagogischen Wünsche auf das wirtschaftlich Machbare treffen“. In: Gürlevik, A., Palentien, C., \& Heyer, R. (eds.), Privatschulen versus staatliche Schulen (pp. 21-38). Wiesbaden: Springer.

5. Maaz, K., Hausen, C., McElvany, N., \& Baumert, J. (2006). Stichwort: Übergänge im Bildungssystem. Theoretische Konzepte und ihre Anwendung in der empirischen Forschung beim Übergang in die Sekundarstufe. Zeitschrift für Erziehungswissenschaft, 9(3), 299-327.

6. Mandel, K., \& Papp, Z. A. (2007). Cammogás. Minőségkoncepciók a romániai magyar középfokú oktatásban. Csíkszereda: Soros Oktatási Központ.

7. OECD (2019), Balancing School Choice and Equity: An International Perspective Based on Pisa, PISA, OECD Publishing, Paris, https://doi.org/10.1787/2592c974-en.

8. Pusztai, G. (2009). A társadalmi tóke és az iskola. Budapest: Mandátum Kiadó.

9. Pusztai, G. (2015). Tőkeelméletek az oktatáskutatásban. In: Varga, A. (eds)., A nevelésszociológia alapjai. (pp. 137-160). Pécs: Pécsi Tudományegyetem, BTK.

10. Schelander, R. (2013). Warum schicken Eltern ihre Kinder auf eine evangelische Schule? Erhebung von Elternmotiven für die Schulwahl. In: Schelander, R. (eds.), Kompetenzorientiert Unterrichten. Diakonie und Schule (pp. 179-212). Schulfach Religion. Jahrg. 31/2012, Nr.1-4. Wien - Berlin: LIT Verlag.

(C) 2020 by the authors. Submitted for possible open access publication under the terms and conditions of the Creative Commons Attribution (CC BY) license (http://creativecommons.org/licenses/by/4.0/). 